\title{
Lack of association between angiotensin-converting enzyme (ACE) genotype and essential hypertension in Peruvian older people
}

\author{
Teodoro J. Oscanoa $\mathbb{( 1}^{1-3}$, Edwin C. Cieza ${ }^{1-3}$, Frank A. Lizaraso-Soto ${ }^{1}{ }^{1}$, María L. Guevara ${ }^{4}$, \\ Ricardo M. Fujita $\mathbb{1}^{4}$, Roman Romero-Ortuno $\mathbb{\circledR}^{5,6}$ \\ 'Universidad de San Martín de Porres, Facultad de Medicina Humana, Instituto de Investigación, Lima, Perú \\ ${ }^{2}$ Hospital Nacional Guillermo Almenara Irigoyen, Servicio de Geriatría. ESSALUD; Lima, Perú \\ ${ }^{3}$ Universidad Nacional Mayor de San Marcos, Facultad de Medicina, Lima, Perú \\ ${ }^{4}$ Universidad de San Martín de Porres, Centro de Investigación de Genética y Biología Molecular, FMH-USMP, Lima, Perú \\ ${ }^{5}$ Discipline of Medical Gerontology, Mercer's Institute for Successful Ageing, St James's Hospital, Dublin, Ireland \\ ${ }^{6}$ Global Brain Health Institute, Trinity College Dublin, Ireland
}

\section{Abstract}

Background: Epidemiological studies have shown an association between the ACE gene I/D polymorphism with arterial hypertension, specifically the $\mathrm{DD}$ genotype, in different populations. The objective of this study is to evaluate the association between ACE polymorphisms (Insertion, Deletion or I/D) and essential hypertension in a population of Lima, Peru.

Material and methods: This is a study of cases (essential arterial hypertension) and controls, with determination of the ACE I/D genotype.

Results: Cases (65) and controls (39) had a mean age (standard deviation) of 74.3 (7.9) and 72.6 (6.5) ( $\mathrm{p}=0.24)$. In cases, the genotype frequencies DD, ID, and II were $6(9.2 \%), 28(43.1 \%)$ and $31(47.7 \%)$, respectively. In controls, the genotype frequencies DD, ID, and II were 6 (15.4\%), 14 (35.9\%) and 19 (48.7\%). The Hardy-Weinberg equilibrium analysis in cases and controls was $\mathrm{p}=0.93$ and $\mathrm{p}=0.23$, respectively. No significant associations between genotype $\mathrm{DD} v$ s. ID + II (OR $=0.56,95 \% \mathrm{CI}: 0.17-1.87, \mathrm{p}=0.34)$ or II $v$ s. $\mathrm{DD}+\mathrm{ID}(\mathrm{OR}=0.95,95 \% \mathrm{CI}$ : $0.43-2.12, \mathrm{p}=0.92$ ) and essential hypertension were found.

Conclusions: The ACE I/D polymorphism was not associated with hypertension in our sample.

Key words: hypertension; renin-angiotensin system; genetic polymorphism; angiotensin converting enzyme; Peru

Arterial Hypertens. 2020, vol. 24, no. 3, pages: 115-119

DOI: $10.5603 / A H . a 2020.0011$

\footnotetext{
Address for correspondence: Teodoro J. Oscanoa, Universidad de San Martín de Porres, Facultad de Medicina Humana,

Centro de Investigación de Seguridad de Medicamentos, Alameda del Corregidor 1531, La Molina 15024. Lima, Perú; Hospital Almenara ESSALUD, Lima - 13, Perú; Universidad Nacional Mayor de San Marcos, Facultad de Medicina, Lima, Perú, tel: (511) 942 820820;

e-mail: tjoscanoae@gmail.com; toscanoae@usmp.pe
}

VM Copyright $(2020$ Via Medica, ISSN 2449-6170 


\section{Introduction}

Hypertension is one of the most common non-communicable diseases in the world, with a prevalence of $22 \%$ [1] and in Peru 23.7\% [2]. Essential hypertension refers to primary hypertension where an aetiology has not been clearly identified. Arterial hypertension has been associated with various risk factors including age, sex, demographic, lifestyle, environmental and genetic. The heritability of hypertension ranges from 48 to $60 \%$ for systolic hypertension and 34 to $67 \%$ for systo-diastolic [3], although it should be noted that heritability does not identify which genetic difference is more significant or the mechanism by which it exerts its effect on blood pressure [3].

Currently, 2129 genes associated with hypertension have been reported, among which is the angiotensin-converting enzyme (ACE) gene [4]. The ACE enzyme converts inactive angiotensin I into active angiotensin II and also degrades bradykinin to maintain homeostasis of blood pressure. ACE is a membrane-bound dipepetidyl carboxypeptidase ectoenzyme, located in the endothelium of blood vessels and is the main component of the reninangiotensin and kallikrein-kinin system. The ACE gene is encoded on the long arm of chromosome 17 (17q23), consists of 26 exons and 25 introns. The presence or absence of a $287 \mathrm{bp}$ element in the ACE gene gives rise to three genotypes: insertion (II), insertion/deletion (I/D) and deletion (DD). Epidemiological studies have shown an association between the ACE gene I/D polymorphism with arterial hypertension, specifically the DD genotype in different populations [5]. On the other hand, certain differences in response have been evidenced in the antihypertensive inhibitors of the angiotensin converting enzyme (ACEI) or angiotensin II receptor blockers (ARBs), according to ACE polymorphism and the study population [5].

The present study aims to evaluate the association between ECA polymorphisms (Insertion/Deletion or I/D) and hypertension essentially in a population of Lima, Peru.

\section{Material and methods}

An observational, retrospective case-control study was carried out. 104 patients (65 cases and 39 controls) equal to or older than 60 years were included. Patients with a diagnosis of essential hypertension verified in clinical history and receiving treatment with antihypertensives for more than 3 months were called cases; and controls were those with a clinical history and evaluation without criteria of arterial hypertension or taking antihypertensives. The study was conducted at the Hospital de Geriátrico of the Almenara Hospital in Lima, Peru, between January 2016 and December 2018. The 104 people of mestizo ancestry, from Lima, who entered the study, were part of an investigation on the use of angiotensin II antagonists, memory performance and its relationship with ACE polymorphisms. The research project was approved by the Almenara Hospital Ethics Committee, and all participants signed an informed consent. The method of patient selection was not probabilistic.

\section{Genomic analysis}

After signing the informed consent, whole blood samples were collected in EDTA tubes of each patient. The DNA was extracted from the leukocytes using the standard phenol/chloroform method and amplified by PCR (polymerase chain reaction). ACE I/D polymorphism (rs1799752) was detected using the method described by Franken et al [6].

\section{Statistical analysis}

Descriptive statistical data were presented as a percentage (\%), mean with standard deviation (SD) and range. The Chi-square analysis was used for the Hardy-Weinberg equilibrium deviation evaluation. The genotype distribution and allele frequencies of each polymorphism were compared between cases and control subjects by the $\chi^{2}$ test. In establishing the association between hypertension and ACE I/D genotypes, the odds ratio (OR) and 95\% confidence intervals $(\mathrm{CI})$ were used. It was considered statistically significant if $\mathrm{p}<0.05$. The SPSS statistical package was used to analyse the data.

\section{Results}

The population studied consisted of 46 men (44.2\%) and 58 women $(55.8 \%)$, with a mean age and standard deviation (SD) of 73.7 (7.4) years, range between 60-90 years. In the population studied the frequency of D/D, I/D and I/I genotypes was $12.65 \%$, $43.66 \%$ and 43.66 respectively, with allelic D and I frequency of $34.5 \%$ and $65.5 \%$ respectively. The analysis of the distribution of genotype frequencies showed that it was consistent with a population in Hardy-Weinberg equilibrium $\left(\chi^{2}=0.1051\right.$; $\mathrm{p}=0.746)($ Tab. 1).

The mean and standard deviation (SD) of age of the cases and controls were 74.34 (7.87) and 72.56 (6.60 years) $(\mathrm{p}=0.24)$. The cases were male 32 
Table 1. Characteristics of the population studied

\begin{tabular}{|c|c|c|c|}
\hline Characteristics & $\begin{array}{l}\text { Controls } \\
(\mathrm{n}=39)\end{array}$ & $\begin{array}{c}\text { Cases } \\
(n=65)\end{array}$ & p value \\
\hline Age ( \pm SD) & $72.56(6.60)$ & $74.34(7.87)$ & 0.24 \\
\hline \multicolumn{4}{|l|}{ Sex } \\
\hline Male (\%) & $14(35.90 \%)$ & $32(49.23 \%)$ & 0.19 \\
\hline Female (\%) & $25(64.10 \%)$ & $33(50.77 \%)$ & 0.19 \\
\hline Body mass index & $27.28(4.21)$ & $28.02(3.89)$ & 0.37 \\
\hline Smoking & $3(7.69 \%)$ & $2(3.13 \%)$ & 0.30 \\
\hline Dyslipidaemia & $9(23.08 \%)$ & $27(41.54 \%)$ & 0.07 \\
\hline Diabetes mellitus type 2 & $7(17.95 \%)$ & $14(21.54 \%)$ & 0.66 \\
\hline \multicolumn{4}{|l|}{ Genotype } \\
\hline $\mathrm{D} / \mathrm{D} \mathrm{n}(\%)$ & $6(15.38 \%)$ & $6(9.23 \%)$ & 0.42 \\
\hline I/D n (\%) & $14(35.90 \%)$ & $28(43.08 \%)$ & 0.47 \\
\hline $\mathrm{l} / \mathrm{ln}(\%)$ & $19(48.72 \%)$ & $31(47.69 \%)$ & 0.92 \\
\hline
\end{tabular}

$\mathrm{SD}$ - standard deviation

Table 2. Relationship between angiotensin convertase enzyme (ACE) polymorphisms and essential hypertension in a population of Lima, Peru

\begin{tabular}{|l|c|c|c|c|c|}
\hline Genotype ACE & Controls $(\mathbf{n}=39)$ & $\begin{array}{c}\text { Cases } \\
(\mathbf{n}=65)\end{array}$ & OR & 95\% Cl & p value \\
\hline $\begin{array}{l}\text { DD vs. ID + II } \\
\mathrm{n}(\%)\end{array}$ & $6(15.38)$ & $6(9.23 \%)$ & 0.56 & $0.17-1.87$ & 0.34 \\
\hline $\begin{array}{l}\text { ID vs. II + DD } \\
\mathrm{n}(\%)\end{array}$ & $14(35.9 \%)$ & $28(43.08)$ & 1.35 & $0.60-3.06$ & 0.47 \\
\hline $\begin{array}{l}\text { II vs. DD + ID } \\
\mathrm{n}(\%)\end{array}$ & $19(48.72)$ & $31(47.9 \%)$ & 0.95 & $0.43-2.12$ & 0.92 \\
\hline $\begin{array}{l}\text { D vs. I } \\
\mathrm{n}(\%)\end{array}$ & $26(33)$ & $40(31 \%)$ & 0.89 & $0.49-1.62$ & 0.70 \\
\hline $\begin{array}{l}\text { The Hardy-Weinberg equilibrium } \\
\text { (p value) }\end{array}$ & 0.23 & 0.93 & & & \\
\hline
\end{tabular}

OR - odds ratio; $\mathrm{Cl}$ - confidence interval

(49\%) and female $33(51 \%)$, while controls were male $14(36 \%)$ and female $25(64 \%)$. In the cases the genotype frequency DD, ID, and II were $6(9.23 \%)$, $28(43.08 \%), 31(47.69 \%)$ respectively. In the controls the genotype frequency DD, ID, and II were 6 (15.38\%), 14 (35.90\%), 19 (48.72\%). The Hardy-Weinberg equilibrium analysis in cases and controls was $p=0.93$ and $p=0.23$ respectively. No significant association of genotype DD vs. ID + II (OR $=0.56$, $95 \%$ CI: $0.17-1.87, \mathrm{p}=0.34)$ or II vs. DD + ID $(\mathrm{OR}=0.95,95 \%$ CI: $0.43-2.12, \mathrm{p}=0.92)$ with essential hypertension was found (Tab. 2).

\section{Discussion}

The present study did not find an association between ACE polymorphisms and essential hypertension in a population of Lima, Peru.
The results of studies on the relationship between ECA polymorphisms and essential hypertension differ significantly depending on the geographic location and population studied. The main study with positive results is the meta-analysis conducted by Mengesha et al. in the African continent, which included 6 studies, finding that patients with the $\mathrm{D}$ allele were 1.49 times more likely to develop essential hypertension compared to the carriers of the I allele (OR: 1.49; CI: 1.07-2.07), additionally found that those from sub-Saharan Africa were more susceptible than those from North Africa [5]. A study conducted in the USA with Mexican-Americans found an association between the $\mathrm{D}$ allele and essential arterial hypertension [7]. Studies in India have also reported an association between the $\mathrm{ACE} /(\mathrm{D} / \mathrm{D})$ genotype and essential hypertension [8-11].

On the other hand, the negative results are reported by Agerholm et al. [12], the meta-analytical 
study included 45 studies in white people in Europe and the US, finding no relationship between the ACE gene and essential hypertension. In addition, two studies have been published with the same negative results between Hawaiian Americans and African Americans $[13,14]$.

In Latin America, a study in Colombia (Bucaramanga) found that DD genotype was 1.56 times more frequent in hypertensive patients, compared to allele I [15]. Bonfim-Silva et al. [16] in their study with Afro-Brazilian and Caucasian population found no association; neither did the study conducted in Cuba in a multi-ethnic sample [17]. A recent study in Brazil also found no relationship; however, this relationship became significant only when ACE and ACE2 polymorphisms were combined [18]. Prior to this study, the only study conducted in Peru (Lima and Chincha), was that of Lizaraso et al. and found no relationship between these polymorphisms and essential hypertension [9].

The importance of knowing the association of ACE gene and essential hypertension is to know if there is a genetic basis in the effectiveness of antihypertensive pharmacotherapy with angiotensin converting enzyme inhibitors (ACEIs) or angiotensin II receptor blockers (ARBs). It has been described that the effectiveness of ACEIs is diminished in the African and African-American population and these antihypertensives are not of first choice in that population $[20,21]$. Coincidentally the ACE D/D genotype is related to essential hypertension in this population [5]. It has been described that the rate of early responses to ramipril is more frequent in patients with genotypes ID and II, compared to DD, in patients from India; once again it is compatible with the finding of the association of DD with $\mathrm{HT}$ in that country [22]. Another study in Malaysia, found that DD carriers respond better to enalapril or lisinopril than ID and II [23]. On the other hand, genotypes II respond better than DD or ID to ARB such as ibersartan [24]. One of the practical objectives of this type of pharmacogenetic studies is to convert the ACE polymorphism determination into a marker of individualized antihypertensive response to ACEIs and ARBs.

The present study has some limitations. The main one is the number of patients is relatively small. However, it provided genetic data that can be used to initiate other studies designed to know the pharmacogenetics of ACEIs and ARBs in the Peruvian population, having ACE genotypes as markers.

In conclusion, the present study did not find an association between ACE polymorphisms (Insertion/ Deletion or I/D) and essential hypertension in the study population. More research is required in different populations of the country, adding other candidate genes.

\section{Acknowledgment}

To all professionals who are part of the Geriatrics Service of Almenara Hospital, Lima Peru.

\section{Funding}

ESSALUD, Kaelin Award, Institute for Health Technology Research and Research (IETSI). Resolution No. 04-IETSI-ESSALUD-2016.

\section{Conflict of interest}

The authors declare no conflict of interest, financial or otherwise.

\section{References}

1. World Health Organization. World Health Statistics Reports on Global Health Goals for 194 Countries. 2015. http://cdrwww.who.int/ mediacentre/news/releases/2015/world-healthstatistics-2015/en.

2. Segura L, Agusti R, Ruiz E. Hipertensión arterial en el Perú según el estudio TORNASOL II. Revista Peruana de Cardiología. 2011; 37(1): 19-27.

3. Waken RJ, de Las Fuentes L, Rao DC. A Review of the Genetics of Hypertension with a Focus on Gene-Environment Interactions. Curr Hypertens Rep. 2017; 19(3): 23, doi: 10.1007/s11906-017-0718-1, indexed in Pubmed: 28283927.

4. Rana G, Yadav S, Joshi S, et al. Association of DD genotype of angiotensin-converting enzyme gene (I/D) polymorphism with hypertension among a North Indian population. J Community Genet. 2018; 9(1): 51-55, doi: 10.1007/s12687-017-0321-9, indexed in Pubmed: 28770441.

5. Mengesha HG, Petrucka P, Spence C, et al. Effects of angiotensin converting enzyme gene polymorphism on hypertension in Africa: A meta-analysis and systematic review. PLoS One. 2019; 14(2): e0211054, doi: 10.1371/journal.pone.0211054, indexed in Pubmed: 30763326

6. Franken R, Bellesso M, Cavazin A, et al. Associaçáo do polimorfismo do gene da enzima conversora da angiotensina com dados ecocardiográficos em jovens normotensos filhos de hipertensos. Rev Assoc Médi Brasil. 2004; 50(1): 62-67, doi: 10.1590/s010442302004000100037.

7. Thameem F, Voruganti VS, He X, et al. Genetic variants in the renin-angiotensin system genes are associated with cardiovascularrenal-related risk factors in Mexican Americans. Hum Genet. 2008; 124(5): 557-559, doi: 10.1007/s00439-008-0581-x, indexed in Pubmed: 18985387.

8. Singh M, Singh AK, Singh S, et al. Angiotensin-converting enzyme gene I/D polymorphism increases the susceptibility to hypertension and additive diseases: A study on North Indian patients. Clin Exp Hypertens. 2016; 38(3): 305-311, doi: 10.3109/10641963.2015 .1107085 , indexed in Pubmed: 27030424.

9. Paramasivam R, Rengasamy N, Arumugam D, et al. Association of ACE DD Genotype with Hypertension among the Tribal Populations of South India. ILNS. 2016; 52: 1-8, doi: 10.18052/www. scipress.com/ilns.52.1.

10. Krishnan R, Sekar D, Karunanithy S, et al. Association of angiotensin converting enzyme gene insertion/deletion polymorphism with essential hypertension in south Indian population. Genes Dis. 2016; 3(2): 159-163, doi: 10.1016/j.gendis.2016.03.001, indexed in Pubmed: 30258884

11. Choudhury I, Jothimalar R, Patra AK. Angiotensin Converting Enzyme Gene Polymorphism and its Association with Hyperten- 
sion in South Indian Population. Indian J Clin Biochem. 2012; 27(3): 265-269, doi: 10.1007/s12291-012-0217-8, indexed in Pubmed: 26405385 .

12. Agerholm-Larsen B, Nordestgaard BG, Tybjaerg-Hansen A. ACE gene polymorphism in cardiovascular disease: meta-analyses of small and large studies in whites. Arterioscler Thromb Vasc Biol. 2000; 20(2): 484-492, doi: 10.1161/01.atv.20.2.484, indexed in Pubmed: 10669647.

13. Henderson SO, Haiman CA, Mack W. Multiple Polymorphisms in the renin- angiotensin-aldosterone system (ACE, CYP11B2, AGTR1) and their contribution to hypertension in African Americans and Latinos in the multiethnic cohort. Am J Med Sci. 2004; 328(5): 266-273, doi: 10.1097/00000441-200411000-00006, indexed in Pubmed: 15545843.

14. Martinez Cantarin MP, Ertel A, Deloach S, et al. Variants in genes involved in functional pathways associated with hypertension in African Americans. Clin Transl Sci. 2010; 3(6): 279-286, doi: 10.1111/j.1752-8062.2010.00242.x, indexed in Pubmed: 21167003

15. Bautista LE, Vargas CI, Oróstegui M, et al. Population-based casecontrol study of renin-angiotensin system genes polymorphisms and hypertension among Hispanics. Hypertens Res. 2008; 31(3): 401408, doi: 10.1291/hypres.31.401, indexed in Pubmed: 18497458.

16. Bonfim-Silva R, Guimarães LO, Souza Santos J, et al. Case-control association study of polymorphisms in the angiotensinogen and angiotensin-converting enzyme genes and coronary artery disease and systemic artery hypertension in African-Brazilians and CaucasianBrazilians. J Genet. 2016; 95(1): 63-69, doi: 10.1007/s12041-0150599-5, indexed in Pubmed: 27019433.

17. Companioni Nápoles O, Sautié Castellanos M, Leal L, et al. ACE I/D polymorphism study in a Cuban hypertensive population. Clin Chim Acta. 2007; 378(1-2): 112-116, doi: 10.1016/j.cca.2006.11.003, indexed in Pubmed: 17196575.

18. Pinheiro DS, Santos RS, Jardim PC, et al. The combination of ACE I/D and ACE2 G8790A polymorphisms revels susceptibility to hypertension: A genetic association study in Brazilian patients. PLoS
One. 2019; 14(8): e0221248, doi: 10.1371/journal.pone.0221248, indexed in Pubmed: 31430320.

19. Lizaraso, F, Rivara G, Torres E, et al. Presencia del genotipo D/D del gen de enzima convertidora de angiotensina y del genotipo 235T del gen de angiotensinógeno como factores de riesgo para sumir un evento coronario agudo. Rev Peru Cardiol. 2002; 28(1).

20. Brewster LM, Seedat YK. Why do hypertensive patients of African ancestry respond better to calcium blockers and diuretics than to ACE inhibitors and $\mathrm{X}$-adrenergic blockers? A systematic review. BMC Med. 2013; 11: 141, doi: 10.1186/1741-7015-11-141, indexed in Pubmed: 23721258.

21. Arnett DK, Davis BR, Ford CE, et al. Pharmacogenetic association of the angiotensin-converting enzyme insertion/deletion polymorphism on blood pressure and cardiovascular risk in relation to antihypertensive treatment: the Genetics of Hypertension-Associated Treatment (GenHAT) study. Circulation. 2005; 111(25): 3374-3383, doi: 10.1161/CIRCULATIONAHA.104.504639, indexed in Pubmed: 15967849 .

22. Gupta S, Chattopadhyaya I, Agrawal BK, et al. Correlation of renin angiotensin system (RAS) candidate gene polymorphisms with response to Ramipril in patients with essential hypertension. J Postgrad Med. 2015; 61(1): 21-26, doi: 10.4103/0022-3859.147028, indexed in Pubmed: 25511213.

23. Heidari F, Vasudevan R, Mohd Ali SZ, et al. Association of insertion/deletion polymorphism of angiotensin-converting enzyme gene among Malay male hypertensive subjects in response to ACE inhibitors. J Renin Angiotensin Aldosterone Syst. 2015; 16(4): 872-879, doi: $10.1177 / 1470320314538878$, indexed in Pubmed: 25002132

24. Kurland L, Melhus H, Karlsson J, et al. Swedish Irbesartan Left Ventricular Hypertrophy Investigation versus Atenolol (SILVHIA) Trial. Angiotensin converting enzyme gene polymorphism predicts blood pressure response to angiotensin II receptor type 1 antagonist treatment in hypertensive patients. J Hypertens. 2001; 19(10): 1783-1787, doi: 10.1097/00004872-200110000-00012, indexed in Pubmed: 11593098. 